\title{
Relevansi Peradilan Pidana Internasional bagi Perlindungan Hak Asasi Manusia
}

\author{
Salman Luthan
}

\begin{abstract}
The intermational criminal justice has a relevance to human rights protection inasmuch as it protects the international community from the practice of crimes such as genocide crimes, humanity crime and aggression and war crime. Additionally, various cases of serious human rights violation occurring in several countries such as Bosnia, Croatia, Kosovo, and East Timor which were carried out by authoritarian regime lead the existence of the international justice to be more relevant. Even though the existence of this justice is relevant in this manner, its implementation provides us with the barrier like institutional weaknesses, authentication difficulties, political power, economy, and military among the UNmembers. Thus, the effectiveness of the intemational criminal justice will be examined by time.
\end{abstract}

\section{Pendahuluan}

Haḱ asasi manusia (HAM) adalah hak kodrati yang secara inheren melekat dalam diri setiap manusia sejak manusia tersebut dilahirkan ke dunia ini. Pengertian ini mengandung arti bahwa HAM merupakan karunia Allah yang maha pencipta kepada setiap hamba-Nya. Mengingat HAM adalah karunia Sang Pencipta, maka tidak ada badan apapun yang dapat mencabut hak itu dari tangan si pemiliknya, tidak seorang pun diperkenankan untuk memperkosanya, dan tidak ada kekuasaan apapun yang boleh membelenggunya. Dengan kata lain, hanya
Tuhan yang dapat mencabut hak tersebut dari tangan manusia.

Karena HAM itu bersifat kodrati, sebenarnya HAM tidak memerlukan legitimasi yuridis untuk memberlakukannya dalam suatu sistem hukum nasional dan internasional. Meskipun tidak ada perlindungan atau jaminan konstitusional terhadap HAM, HAM itu tetap ada dalam diri setiap manusia.

Gagasan HAM yang bersifat teistik ini diakui kebenarannya sebagai nilai yang paling hakiki dalam kehidupan manusia. Namun, karena sebagian besar tata kehidupan 
manusia bersifat sekuler dan positivistik, maka eksistensi HAM memerlukan landasan yuridis untuk diberlakukan dalam mengatur kehidupan manusia. Oleh karena itu, pengaturan HAM dalam konvensi-konvensi PBB dan konstitusi negara yang berisi pengakuan terhadap HAM harus dipahami dalam konteks tata kehidupan. sosial yang sekuler dan positivistik tersebut.

HAM mempunyai kedudukan penting bagi setiap individu karena langsung berkaitan dengan penghargaan dan pengakuan terhadap eksistensi manusia selaku insan yang bebas dan merdeka. Sebagai insan merdeka, setiap orang memiliki hak hidup, memiliki kebebasan untuk mengekspresikan diri, berpikir dan berpendapat, menganut suatu keyakinan, dan kebebasan untuk bertindak menurut keyakinannya'sepanjang tidak melanggar HAM orang lain. Tanpa HAM, manusia kehilangan eksistensi kemanusiaannya. Dengan kata lain HAM merupakan tolok ukur terhadap harkat dan martabat manusia.

Dengan demikian, dapat dikatakan bahwa HAM merupakan kebutuhan esensial yang sesuai dengan fitrah kemanusiaan. Suasana kehidupan yang bebas dan merdeka tidak dapat diganti dengan barang atau jasa apapun. Sebab inti dari kemerdekaan adalah kemerdekaan itu sendiri. Begitu pula kebutuhan terhadap hak hidup, nilai-nilai persamaan, keadilan dan kebenaran.

Hak asasi manusia yang berisi hak-hak dasar manusia berfungsi untuk mengatur tata pergaulan manusia, baik yang menyangkut hubungan individu dengan individu, hubungan individu dengan negara (penguasa), hubungan sosial kemasyarakatan, maupun hubungan antar negara. Fungsi HAM yang utama adalah untuk mengatur hubungan individu dengan penguasa.

HAM sering disalah-tafsirkan sebagai konsep Barat, sehingga HAM dianggap identik dengan nilai-nilai Barat, yang tidak harus diikuti oleh bangsa-bangsa lain (non-Barat). Adanya salah tafsir ini tidak terlepas dari pemutarbalikkan sejarah HAM oleh pakar Barat, yang menganggap fase awal tumbuhnya gagasan HAM adalah Magna Charta (1215).

Pengakuan hak-hak individu (terhadap negara) ini tidaklah hanya dikenal dalam sejarah dan teori politik Barat. Weeramantry (guru besar hukum di Monash University, Melbourne) mengetengahkan perlunya disadari bahwa hak asasi manusia itu mempunyai latar belakang antar kebudayzan (intercultural). Pemikiran Islam misalnya, tentang hak-hak di bidang sosial, ekonomi, dan budaya (social, economic and cultural rights) telah mendahului pemikiran Barat. ${ }^{1}$

$$
\text { Selanjutnya dikemukakan }
$$
Weeramantry"...... Islamic teaching arrived much earlier than the West at the core doctrines of human rights that certain rights are inalienable and that rulers hold their power upon and only so long as they honour trust. These principles were control to Islamic political theory eight years before Lock gave them their first form in the West. ${ }^{2}$

Tonggak sejarah dan politik Islam mengenai HAM berawal dari Konstitusi

'Mardjono Reksodiputro mengutip Weeramantry dalam 1994. Hak Asasi Manusia dan Sistem Peradilan Pidana. Jakarta: Pusat Pelayanan Keadilan dan Pengabdi Hukum UI. HIm. 3.

${ }^{2}$ Ibid. 
Madinah atau Piagam Madinah (624 M) yang bertujuan untuk menyatukan warga yang majemuk baik karena perbedaan etnik (Yahudi dan kelompok-kelompok Arab), perbedaan agama (Yahudi, Muslim dan Nasrani), maupun perbedaan kebudayaan. Dengan demikian, bukan hanya delapan abad Islam mendahului Barat dalam konsep HAM, melainkan hampir 10 abad. $^{3}$

Isi piagam tersebut antara lain, perlindungan kebebasan agama dan beribadah (Pasal 25 dan 30), kedudukan yang sama sebagai anggota masyarakat dan larangan perlakuan buruk terhadap orang (Pasal 16), persamaan hak dan kewajiban yang sama (Pasal 29, 33 dan 44), dan persamaan di depan hukum (Pasal 34, 36, 44).

Dengan demikian, jelas bahwa HAM milik berbagai kebudayaan dan bangsa. Bahkan sekarang ini menurut Weissbrodt dan Vasak, bahwa HAM telah menjadi ideologi universal. ${ }^{4}$ Gagasan perlindungan HAM telah disepakati oleh bangsa-bangsa di dunia sebagai cita-cita luhur kemanusiaan tertuang dalam Universal Declaration of Human Rights, yang dikeluarkan PBB pada tanggal 10 Desember 1948. Deklarasi ini ditandatangani dan disetujui oleh hampir seluruh negara di dunia, termasuk Indonesia.

Universal Declaration of Human Rights (UDHR) merupakan deklarasi Perserikatan
Bangsa-Bangsa (PBB) pertama tentang HAM. Sampai sekarang ada sekitar 30 Konvensi PBB yang mengatur tentang $H A M$, misalnya Kovenan Hak-hak Sipil dan Politik, Kovenan Hak-hak Sosial, Ekonomi dan Kebudayaan, Perlindungan Hak-hak Anak, Perlindungan Hak-hak Wanita, Konvensi Untuk menentang Penyiksaan dan Perlakuan atau Hukuman Lain Yang Kejam, Tidak Manusiawi dan Merendahkan Martabat manusia.

Kovensi-konvensi HAM tersebut berusaha berbicara kepada seluruh umat manusia dengan satu bahasa dan konvensi-konvensi itu memberikan parameter prilaku yang sama luasnya bagi semua negara. Akan tetapi akan tidak realistislah.kiranya untuk mengemukakan. dalam bentuk yang kaku skema hubungan yang sama antara pemerintah dan individu untuk semua negara di dunia, dengan kata lain, konvensi itu tidak akan dapat memproyeksikan ke pentas dunia model masyarakat yang sama dan model negarayang sama. $^{5}$

Cukup apabila dicatat bahwa konvensikonvensi itu dirumuskan oleh negara-negara yang sangat bermacam ragam jenisnya. Masing-masing negara dibiarkan secara bebas mengadakan tatanan kelembagaan dan sistem politik yang paling sesuai dengannya, yang paling baik menggambarkan kebutuhan rakyat dan tradisi nasionalnya. ${ }^{6}$

${ }^{3}$ Nourouzzaman Shidiqi dalam M. Lukman Hakim (ed). 1993. Deklarasilslam Tentang HAM. Surabaya: Risalah Gusti. Hlm: 178-187.

${ }^{4}$ Scot Davidson mengutip Weissbrodt dan Vasak dalam 1994. Hak Asasi Manusia. Jakarta: Pustaka Utama Graviti. HIm. 145.

${ }^{5}$ Antonio Cassese. 1994. Hak Asasi Manusia Di Dunia Yang Berubah. Jakarta: Yayasan Obor Indonesia. HIm. 65-66.

'bid. 
Dalam sistem hukum nasional, pengaturan HAM dirumuskan dalam konstitutsi atau peraturan perundang-undangan yang menunjukkan adanya pengakuan dan perlindungan HAM dalam negara tersebut. Pengakuan dan perlindungan HAM tersebut merupakan pedoman bagi penguasa negara untuk mengatur kehidupan bermasyarakat, berbangsa dan bernegara, serta sekaligus dasar hukum bagi setiap anggota masyarakat untuk menuntut pelanggaran-pelanggaran HAM yang dilakukan penguasa dan masyarakat.

Pengäkuan dan perlindungan HAM dalam konteks sistem hukum dapat dilakukan melalui instrumen hukum tata negara, hukum perdata, hukum internasional, dan hukum pidana. Perlindungan HAM melalui hukum pidana dirumuskan dalam hukum pidana materil, hukum acara pidana, dan hukum pidana internasional. Kharakteristik perlindungan HAM melalui hukum pidana dilakukan melalui larangan penentapan pelanggaran HAM sebagai tindak pidana dan pembatasan kekuasaan aparat penegak hukum melalui sistem peradilan pidana, baik peradilan pidana domestik maupun peradilan pidana internasional. Perlindungan HAM melalui peradilan pidana internasional juga merupakan perindungan HAM menurut hukum intemasional.

\section{Peradilan Pidana Internasional}

Peradilan Pidana Internasional (International Criminal Court) dibentuk berdasarkan Statuta Roma (Rome Statute) pada tanggal 17 Juli 1998, dan berkedudukan di The Haque,
Belanda: Lembaga peradilan ini merupakan instrumen PBB yang berfungsi melaksanakan tugas yudisial mengenai kejahatan-kejahatan serius yang menjadi keprihatinan masyarakat internasional. Peradilan pidana internasional merupakan institusi pelengkap bagi sistem peradilan pidana domestik yang dimiliki setiap negara. $^{7}$

Di samping mengatur pembentukan peradilan pidana internasional, Statuta Roma juga mengatur yurisdiksi, admissability dan penerapan hukum, prinsip-prinsip hukum pidana, komposisi dan administerasi peradilan, investigasi dan penuntutan, peradilan, sanksi, banding dan revisi. Materi lain yang diatur adalah kerjasama internasional dan bantuan yudisial, penegakan, majelis negara anggota, keuangan, dan klausul akhir.

Yurisdiksi peradilan pidana internasional meliputi kejahatan genosaid (the crime of genocide); kejahatan terhadap kemamusiaan (crimes against humanity), kejahatan perang (war crimes), dan kejahatan agresi (the crime of agression). ${ }^{8}$ Keempat jenis kejahatan tersebut menupakan kelompok kejahatan paling serius dalam kaca mata masyarakat internasional dalam beberapa tahun terakhir.

Kejahatan genosaid adalah beberapa tindakan yang dilakukan dengan niat untuk merusak seluruhnya atau sebagian suatu bangsa, etnis, kelompok ras atau agama, seperti pembunuhan anggota-anggota kelompok, menyebabkan bahaya kerusakan mental dan badan bagi anggota kelompok, dengan sengaja mengakibatkan kondisikondisi kehidupan kelompok yang

7Pasal 1-3 Statuta Roma.

•Pasal 5 Statuta Roma. 
diperhitungkan menimbulkan kerusakan fisik seluruhnya atau sebagian; memaksakan tindakan-tindakan dengan niat untuk mencegah kelahiran dalam kelompok, dan dengan paksa memindahkan anak-anak dari suatu kelompok kepada kelompok lain. ${ }^{9}$

Kejahatan terhadap kemanusiaan adalah sejumlah tindakan yang dilakukan sebagai bagian dari suatu serangan langsung yang luas atau sistematik, dengan pengetahuan tentang serangan: pembunuhan, pembasmian atau pemusnahan (extermination), perbudakan, deportasi atau pengusiran paksa penduduk, pemenjaraan atau penghilangan secara kejam kebebasan fisik, yang kesemuanya merupakan pelanggaran aturan-aturan dasar hukum internasional.

Di samping itu, lingkup kejahatan kemanusiaan juga meliputi penyiksaan, perkosaan, perbudakan seks, prostitusi yang dipáksakan, kehamilan yang dipaksa, sterilisasi yang dipaksakan, penyiksaan terhadap beberapa kelompok yang diidentifikașikan kolektivitas politik, ras, negara, etnis, budaya, agama, dan gender, penghilangan orang secara paksa, dan kejahatan apartheid. ${ }^{10}$

Kejahatan perang yang termasuk dalam peradilan pidana internasional adalah kejahatan perang yang dilakukan sebagai bagian dari suatu rencana atau kebijakan atau sebagai bagian dari suatu skàla besar pelaksanaan kejahatan dimaksud: Dalam kaitan ini yang dimaksud dengan kejahatan perang adalah pelanggaran-pelanggaran penting terhadap Konvensi Genewa 12 Agustus 1949. Beberapa tindakan berikut terhadap orang atau barang yang dilindungi. di bawah ketentuan-ketentuan yang relevan dari Konvensi Genewa, yaitu: pembunuhan disengaja, 'penyiksaan atau perlakuan tidak manusiawi, termasuk eksperimen biologi, dengan sengaja menyebabkan penderitaan berat, atau pelukaan serius terhadap badan dan kesehatan, perusakan luas dan pemberian barang kebutuhan militer yang dibawa, secara melawan hukum, memaksa tahanan perang atau orang lain yang dilindungi untuk membantu kekuatan musuh, dengan sengaja mencabut/menghilangkan hak-hak seorang tawanan perang atau orang lain yang dilindungi dari peradilan yang jujur dan teratur, deportasi yang melawan hukum, atau kurungan yang melawan hukum, dan mengambil sandera. ${ }^{11}$

Kejahatan agresi yang menjadi yurisdiksi peradilan pidana internasional dikaitkan dengan ketentuan-ketenmtuan yang terdapat dalam piagam PBB, khususnya ketentuan Pasal 121 dan 122 yang intinya melakukan intervensi dan penyerangan terhadap negara lain. ${ }^{12}$ Pelanggaran terhadap keempat jenis kejahatan yang menjadi yurisdiksi peradilan pidana internasional akan diadili melalui peradilan pidana internasional.

Sanksi pidana yang diancamkan terhadap kejahatan genosaid, kejahatan terhadap kemanusiaan, kejahatan perang, dan

${ }^{9}$ Pasal 6 Statuta Roma.

10Pasal 7 Statuta Roma.

"Pasal 8 Statuta Roma.

${ }^{12}$ Pasal 9 Statuta Roma. 
kejahatan agresi adalah salah satu di antara: pidana penjara untuk jangka watu tertentu, yang tidak boleh lebih dari 30 tahun, penjara seumur hidup bila dibenarkan oleh kegawatan luar biasa dari kejahatan dan kondisi-kondisi individual dari orang yang dituntut. Di samping pemenjaraan, pengadilan dapat menjatuhkan suatu denda dengan kriteria yang disediakan oleh aturan-aturan prodedural dan pembuktian, dan suatu denda/penebusan dari pendapatan dan kekayaan yang secara langsung atau tidak langsung berasal dari kejahatan itu tanpa berprasangka terhadap hak pihak ketiga. ${ }^{13}$

Bagian komposisi dan administrasi peradilan mengatur tentang organ atau kelembagaan dari institusi peradilan pidana internasional. Kelembagaan peradilan pidana internasional terdiri dari empat organ, yaitu kepresidenan, divisi banding, divisi peradilan, dan divisi pra-peradilan, ${ }^{14}$ kantor penuntut umum, dan kepaniteraan.

Dibandingkan dengan organ peradilan domestik di setiap negara, maka terlihat jelas adanya perbedaan kelembagaan antara peradilan pidana internasional dan peradilan domestik. Dalam kelembagaan peradilan domestik hanya terdiri dari unsur hakim dan kapaniteraan, tapi dalạm peradilan pidana internasional termasuk pula lembaga penuntut umum.

Kepresidenan adalah lembaga yang memiliki fungsi untuk mengorganisasikan administerasi peradilan pidana internasional.
Struktur lembaga ini terdiri dari seorang presiden dan dua orang wakil presiden (wakil presiden pertama dan wakil presiden kedua) yang dipilih oleh hakim-hakim peradilan pidana internasional yang diangkat oleh negara-negara anggota untuk jangka waktu tiga tahun atau sampai berakhir masa jabatan mereka sebagai hakim.

Presiden, bersama dengan wakil presiden pertama dan wakil pesiden kedua, memimpin dan menjalankan kepresidenan, yang bertanggungjawab terhadap (a) administerasi peradilan yang pantas, kecuali administerasi kantor penuntut umum, (b) berkoordinasi dan mencari persetujuan dengan Penuntut Umum dalam semua masalah yang menjadi keprihatinan keduanya, (c) mengajukan penambahan jumlah hakim kepada negeranegara anggota, dan (d) fungsi-fungsi lain yang diberikan kepadanya oleh Statuta. ${ }^{15}$

Divisi praperadilan, divisi peradilan, dan divisi banding merupakan organ pelaksana fungsi yudisial untuk memeriksa, mengadili, dan memutuskan perkara. Ketiga organ yudisial ini akan mempunyai 18 hakim yang merupakan anggota penuh peradilan dan disiapkan untuk melayani keperluan peradilan mulai dari masa awal kerja mereka. ${ }^{16}$ Para hakim yang dipilih oleh Negara-negara Anggota bekerja untuk jangka waktu tiga tahun dan dapat dipilih kembali sebanyak satu kali untuk jangka waktu yang sama.

Setiap calon hakim yang akan dipilih harus: (i) mempunyai kompetensi yang mapan

\footnotetext{
${ }^{13}$ Pasal 77 Statuta Roma.

${ }^{14}$ Praperadilan dalam konteks ini adalah pemeriksaan sebelum proses peradilan.

${ }^{15}$ Pasal 38 Statuta Roma.

${ }^{16}$ Pasal 37 Statuta Roma.
} 
dalam hukum pidana, hukum acara pidana, dan pengalaman relevan yang diperlukan, apakah sebagai hakim, penuntut umum, atau dalam kapasitas yang sama, dalam proses pidana, atau (ii) mempunyai kompetensi baik yang relevan dalam bidang hukum internasional seperti hukum humaniter dan hukum hak-hak asasi manusia, dan pengalaman luas dalam bidang profesi hukum yang relevan untuk kerja-kerja yudisial dari peradilan. Di samping itu, setiap calon hakim harus mempunyai pengetahuan yang baik dan lancar sekurang-kurangnya dalam salah satu bahasa yang disyaratkan statuta. ${ }^{17}$

Komposisi majelis hakim yang ditugaskan dalam masing-masing bagian peradilan adalah divisi praperadilan dan divisi praperadilan masing-masing terdiri dari sekurang-kurangnya enam hakim,sedangkan divisi banding terdiri dari seorang presiden dan empat hakim lainnya. Majelis hakim banding akan berasal dari hakim-hakim divisi banding, majelis hakim peradilan akan dilaksanakan oleh tiga hakim dari. hakim divisi peradilan. Majelis hakim Praperadilan akan dilaksanakan oleh tiga hakim dari divisi praperadilan atau oleh seorang hakim yang sesuai dengan Statuta dan aturañ prosedur dan pembuktian. Masingmasing majelis hakim terdiri dari komposisi ahli hukum pidana dan hukum acara pidana dan hukum inernasional. ${ }^{18}$
Hakim peradilan pidana internasional dijamin independensinya oleh Statuta. Hakim harus independen dalam penampilan dan fungsinya, dan hakim tidak boleh terikat dalam kegiatan yang cenderung mencampuri fungsi yudisial mereka dan mempengaruhi kepercayaan dan independensinya. Disamping itu, selama bertugas sebagai hakim peradilan, para hakim tersebut cidak boleh bekerja pada pekerjaan lain. ${ }^{19}$

Mengenai kewenangan masing-masing majelis hakim dapat dijelaskan sebagai berikut. Majelis praperadilan memiliki wewenang yang meliputi:

1. Jika majelis praperadilan setelah memeriksa permohonan dan materi pendukung, mempertimbangkan bahwa ada dasar rasional untuk memproses suatu investigasi, dan bahwa kasus itu termasuk yurisdiksi peradilan pidana internasional, majelis memerintahkan untuk diadakan investigasi, ${ }^{20}$

2. Atas permintaan penuntut umum mengesahkan hasil investigasi, yang dilakukan negara, anggota atas perintah penuntut umum, ${ }^{21}$

3. Menyelesaikan sengketa yurisdiksi dan suatu kasus yang sudah diproses,

4. Pengesahan hasil investigasi,

5. Melindungi informasi kepentingan nasional suatu negara, ${ }^{22}$

\footnotetext{
${ }^{17}$ Pasal 36 Statuta Roma.

${ }^{18}$ Pasal 39 Statuta Roma.

${ }^{19}$ Pasal 40 Statuta Roma.

20Pasal 15 Statuta Roma.

${ }^{21}$ Pasal 18 Statuta Roma.

${ }^{22}$ Pasal 72 Statuta Roma.
} 
6. Mengeluarkan perintah atau surat perintah yang diperilukan untuk tujuan investigasi, ${ }^{23}$

7. Bila perlu menyediakan perlindungan terhadap privasi korban, saksi, dan pelaku, ${ }^{24}$

8. Mengeluarkan surat penahanan atas permintaan penuntut umum jika ada alasan yang cukup kuat ${ }^{25}$

9. Mempersiapkān dan mengadakan pemeriksaan awal sebelum peradilan, ${ }^{26}$

10. Menegaskan tuntutan sebelum penuntutan peradilan:?

Fungsi dan kekuasaan majelis peradilan meliputi:

1) Fungsi-fungsi dan kekuasaan majelis peradilan yang dikemukakan dalam pasal ini dijalankan sesuai dengan statuta dan aturan prosedur dan pembuktian,

2) Harus menjamin bahwa peradilan berjalan secara jujur dan tepat guna dan dilaksanakan dengan sepenuhnya menghormati hak-hak tersangka, perlindungan korban-korban dan saksisaksi.

3) Dalam upaya memeriksa kasus:

a) Berunding dengan pihak-pihak dan mengadopsi prosedur yang diperlukan untuk memfasilitasi perbuatanperbuatan yang fair dan tepat dalam pemeriksaan.

b) Menentukan bahasa yang digunakan dalam persidangan
c) Pembukaan dokumen

4) Dalam melaksanakan tugasnya dapat, jika diperlukan:

a. Menguji fungsi majelis praperadilan,

b. Meminta kehadiran dan kesaksian dari saksi, dan dokumen yang dimiliki,

c. Menyediakan perlindungan informasi rahasia,

d. memerintahkan pengeluaran buktibúkti,

e. perlindungan pelaku, saksi dan korban.

5) Repatriasi kembali para korban, termasuk restitusi dan kompasasi serta rehabilitasi.

Majelis banding berwenang dan bertanggungjawab untuk memeriksa, mengadili dan memutuskan perkara banding yang diajukan oleh para pihak yang tidak dapat menerima putusan praperadilan dan putusan peradilan. Dengan kata lain, banding dapat diajukan terhadap putusan pembebasan atau putusan penjatuhan hukuman.

Banding dapat diajukan oleh penuntut umum dan terpidana. Penuntutan umum dapat menggunakan banding atas beberapa alasan, yaitu kesalahan prosedur (error of procedure), kesalahan fakta (error of facts), kesalahan hukum. (error of law). Terpidana atau-penuntut umum atas nama kepentingan seseorang, dapat menggunakan banding karena alasan tersebut di atas, dan alasan-alasan lain yang mempengaruhi kejujuran dan reliabilitas pemeriksaan atau peradilan..$^{28}$

${ }^{23}$ Pasal 57 Statuta Roma.

- ${ }^{24}$ Pasal 57 Statuta Roma.

${ }^{25}$ Pasal 58 Statuta Roma.

${ }^{26}$ Pasal 60 Statuta Roma.

27Pasal 61 Statuta Roma.

${ }^{28}$ Pasal 81 Statuta Roma. 
Banding dapat pula dilakukan terhadap putusan mengenai penetapan yurisdiksi, putusan persetujuan atau penyangkalan pelepasan tersangka/terdakwa, dan putusan majelis praperadilan, serta putusan yang mempengaruhi peradilan yang jujur, tepat dan tidak memihak.

Kantor penuntut umum akan bertindak secara independen sebagai organ terpisah dari peradilan dalam menjalankan tugas dan fungsinya. Kantor penuntut umum akan dikepalai oleh seorang kepala penuntut umum yang mempunyai otoritas penuh terhadap manajemen dan administerasi kantor, termasuk staf, fasilitas dan keperluan lainnya. Kepala penuntut umum akan dibantu oleh seorang atau lebih deputi penuntut umum yang akan ditugasi untuk menjalankan tindakan-tindakan yang diperlukan mengenai penuntutan dalam rangka statuta ini.

Kepala penuntut umum dipilih secara rahasia oleh suatu mayoritas mutlak dari suara Majelis Negara-negara Anggota. Deputi penuntut umum akan dipilih dengan cara yang sama dari daftar calon yang diajukan oleh kepala penuntut umum. Kepala penuntut umum akan mengusulkan/mencalonkan tiga kandidat untuk setiap poisisi deputi penuntut umum yang akan diisi. Kepala penuntut umum dan deputi penuntut umum akan berasal dari kebangsaaan/negara yang berbeda dan bekerja secara penuh.

Kantor penuntut umum akan bertanggung jawab untuk menerima pengaduan, penyerahan informasi yang mendukung terhadap kejahatan yang menjadi yurisdiksi peradilan, untuk mengujinya dan melakukan tindakan investigasi dan penuntutan sebelum praperadilan. Penuntut umum bekerja secara independen dalam melaksanakan tugasnya. ${ }^{29}$ Kepala penuntut umum dapat menunjuk investigator untuk membantu pekarjaan mereka. ${ }^{30}$

Penuntut umum melakukan investigasi untuk mengumpulkan bahan-bahan dan untuk melengkapi bahan-bahan yang sudah ada guna melakukan penuntutan. Apabila Penuntut Umum menyatakan tidak cukup bukti untuk memproses suatu kasus, maka penutupan perkara itu hanya dapat diterima jika disetujui oleh majelis praperadilan. ${ }^{31}$

Baik kepala penuntut umum maupun deputi penuntut umum tidak akan mengikatkan diri dalam aktivitas yang cenderung dapat mengintervensi fungsi penuntut umum atau untuk mempengaruhi kepercayaan terhadap indpendensi mereka. Baik Kepala Penuntut Umum maupun Deputi Penuntut Umum tidak akan berpartisipasi dalam masalah-msalah dimana ketidakberpihakan mereka mungkin diragukan secara rasional atas beberapa pertimbangan.

Organ kepaniteraan bertanggung-jawab terhadap aspek-aspek nonyudisial dari administerasi dan pelayanan peradilan, tanpa prasangka terhadap fungsi-fungsi dan kekuasaan penuntut umum ${ }^{32}$ Kepaniteraan akan dipimpin oleh seorang kepala panitera yang merupakan pegawai administrasi utama dari peradilan. Kepala panitera akan

\footnotetext{
${ }^{29}$ Pasal 42 dan Pasal 53 Statuta Roma.

${ }^{30}$ Pasal 44 Statuta Roma.

31Pasal 53 Statuta Roma.

${ }^{32}$ Pasal 43 Statuta Roma.
} 
menjalankan fungsinya di bawah otoritas presiden dari Peradilan.

Kepala Panitera akan membentuk suatu Unit Korban dan Saksi dalam kepaniteraan. Unit ini akan menyediakan, melalui konsultasi dengan kantor penuntut umum, tindakan perlindungan, rencana pengamanan, konseling dan bantuan lain yang layak bagi saksi, korban yang muncul sebelum peradilan, dan orang lain yang berada dalam resiko berkaitan dengan kesaksian yang diberikan para saksi. Unit akan termasuk staf yang ahli dalam trauma, termasuk trauma dalam hubungan kejahatan-kejahatan tentang kekerasan seksual. .

Peradilan pidana internasional memuat prinsip-prinsip umum hukum pidana yang sudah baku, baik asas-asas hukum pidana materil maupun asas-asas hukum pidana formil (hukum acara pidana). Prinsip-prinsip hukum pidana materiil ada enam macam. Pertama, asas nullum crimen sine lege, artinya, seseorang tidak akan bertanggung jawab secara pidana menurut statuta kecuali perbuatan yang dipertanyakan merupakan, pada saat perbuatan itu dilakukan, kejahatan menurut yurisdiksi peradilan.

Dalam kaitan dengan asas ini ditegaskan bahwa pengertian kejahatan akan diinterpretasikan secara ketat dan tidak akan diperluas dengan analogi. Apabila ada ambiguitas, pengertian kejahatan akan diinterpretasikan dalam mendukung seseorang yang sedang diinvestigasi, dituntut atau dihukum.
Kedua, asas nula poena sine.lege, yang esensinya adalah bahwa seseorang dihukum oleh pengadilan hanya dapat dilakukan dengan ketentuan yang terdapat dalam statuta. Ketiga, asas non-retroactive ratione persone (asas nonretroaktii). Maksudnya, tak sorangpun bertanggung jawab secara pidana menurut statuta terhadap tindakan sebelum masuk dalam ketentuan statuta. Dengan kata lain, ketentuan hukum pidana tidak berlaku surut.

Keempat; jika terjadi perubahan perundangundangan terhadap kasus yang melanggar ini, maka digunakan ketentuan hukum yang menguntungkan orang yang diinvestigasi atau dituntut. Kelima, pertanggungjawaban pelaku kejahatan dalam lingkup peradilan pidana internasional bersifat individual. Seseorang yang melakukan kejahatan dalam yurisdiksi peradilan pidana internasional secara individual akan bertanggung jawab agar dapat dihukum dalam hubungan dengan statuta. ${ }^{33}$

Esensi pertanggungjawaban pidana berlandaskan kepada unsur mental elemen, artinya seseorang mampu bertanggung jawab hanya jika elemen material dilakukan dengan niat dan pengetahuan. Dengan kata lain, pertanggungjawaban pidana dapat dimintakan bila ada unsur kesengajaan dalam terjadinya kejahatan dan mengetahui bahwa kejahatan itu merupakan perbuatan terlarang. ${ }^{34}$

Kebijakan pertanggungjawaban pidana tidak membedakan status personal berdasarkan kapasitas ofisialnya. Kapasitas ofisial seperti kepala pemerintahan negara,

\footnotetext{
${ }^{33}$ Pasal 25 Statuta Roma.

${ }^{34}$ Pasal 30 Statuta Roma.
} 
anggota dari suatu pemerintahan atau parlemen, wakil rakyat yang dipilih atau pegawai pemerintah tidak ada pengecualian seseorang dalam pertanggungjawaban pidana dan alasan untuk pengurangan hukuman..$^{35}$

Statuta ini juga mengatur tanggung jawab komandan atau atasan (dalam: Pasal 28) dalam pertanggungjawaban pidana. Seorang komandan militer atau orang yang secara efektif bertindak sebagai komandan militer akan bertanggung jawab sẹcara hukum pidana atas kejahatan dalam lingkup peradilan yang dilakukan oleh kekuatan yang berada di bawah komando dalam kontrol efektifnya, atau otoritas efektif dan kontrol pada kasus yang mungkin ada, sebagai akibat dari kegagalannya untuk melaksanakan kontrol atas kekuatan tersebut. ${ }^{36}$

Keenam, asas nebis in idem, yang maksudnya seseorang tidak akan dituntut untuk kedua kalinya dalam tindak pidana yang sama yang telah dilakukannya. Penuntutan untuk kedua kalinya tidak hanya berlaku dalam lingkup peradilan pidana internasional, tapi juga dalam hubungannya dengan sistem peradilan pidana domestik yang dimiliki oleh suatu negara.

Asas yang terdapat dalam hukum acara pidana yang diadopsi dalam peradilan pidana internasional ini adalah asas praduga tidak bersalah (presumption of innocence).
Seseorang yang melakukan kejahatan harus dianggap tidak bersalah sebelum dibuktikan bersalah oleh hasil proses peradilan. ${ }^{37} \mathrm{Di}$ samping asas tersebut, diakui pula asas penghormatan hak-hak terdakwa ${ }^{38}$ dan asas perlibndungan korban dan saksi serta partisipasi mereka dalam pemeriksaan. ${ }^{39}$

Untuk kelancaran dan keberhasilan pelaksanaan peradilan pidana internasional, negara-negara anggota akan bekerjasama secara penuh dengan peradilan dalam kegiatan investigasi dan penuntutannya mengenai kejahatan-kejahatan yang menjadi yurisdiksinya. ${ }^{40}$ Peradilan mempunyai otoritas untuk mengajukan permintaan kepada negara anggota untuk bekerjasama. Permintaan dapat dilakukan melalui cara diplomasi atau cara lain yang patut seperti dapat dirancang oleh setiap negara anggota melalui ratifikasi, penerimaan, persetujuan, atau pemberian jalan.

\section{Relevansi Perlindungan HAM}

Keberadaan peradilan pidana internasional mempunyai relevansi yang kuat" dengan perlindungan HAM pada masa sekarang dan di waktu yang akan datang. Relevansi itu bukan hanya untuk tata pergaulan internasional antar bangsa dan negara, tapi bisa juga dalam hubungan domestik antara rejim yang berkuasa dengan rakyatnya, terutama di negara-negara yang diperintah

\footnotetext{
${ }^{35}$ Pasal 27 Statuta Roma.

${ }^{36}$ Pasal 28 Statuta Roma.

${ }^{37}$ Pasal 65 Statuta Roma.

${ }^{38}$ Pasal 67 Statuta Roma.

${ }^{39}$ Pasal 68 Statuta Roma.

${ }^{40}$ Pasal 86 Statuta Roma.
} 
oleh pemerintahan otoriter. Ada beberapa argumen yang dapat diajukan untuk mengaitkan keberadaan peradilan pidana internasional dengan perlindungan HAM.

Pertama, hukum pidana internasional merupakan salah satu instrumen perlindungan HAM yang berintikan pada larangan melakukan tindakan-tindakan yang melanggar HAM, yang dalam terminologi hukum pidana disebut sebagai perbuatan terlarang atau tindak pidana atau kejahatan. Larangan melanggar HAM tersebut tidak hanya ditujukan terhadap individu dan komunitas, tapi terutama kepada para penguasa yang mengendalikan pemerintahan negaranya masing-masing.

Pérbuatan-perbuatan individu, komunitas, dan negara yang dikualifikasikan sebagai pelanggaran HAM dalam ketentuan peradilan pidana internasional meliputi kejahatan genosaid, kejahatan terhadap kemanusiaan, kejahatan perang, dan kejahiatan agresi. Kejahatan genosaid merupakan perbuatanperbuatan yang dilakukan sebagai upaya únituk membasmi suatu bangsa, etnis, ras, dan agama. Bentuk-bentuk perbuatan itu bisa berupa pembunuhan, penyiksaan, larangan melahirkan dalam suatu kelompok, dan pemindahan paksa anak-anak dari suatu kelompok kepada kelompok lain.

Kejahatan terhadap kemanusiaan adalah. sejumlah tindakan luas dan sistematik untuk melakukan pembunuhan, pembasmian atau "pemusnahan (extermination), perbudakan, deportasi atau pengusiran paksa, perkosaan, perbudakan seks, prostitusi yang dipaksakan, kehamilan yang dipaksa, dan sterilisasi yang dipaksakan.
Kejahatan perang yang termasuk dalam peradilan pidana internasional adalah pembunuhan disengaja, penyiksaan atau perlakuan tidak manusiawi, termasuk eksperimen biologi, penyiksaan, memaksa tahanan perang jadi tameng pertahanan, marampas hak-hak tawanan perang atau deportasi yang melawan hukum, atau kurungan yang melawan hukum, dan mengambil sandera. Kejahatan agresi adalah tindakan melakukan intervensi dan penyerangan terhadap negara lain.

Kedua, semakin banyak pelanggaranpelanggaran HAM berat dalam satu dekade terakhir, khususnya yang terjadi dalam perang dan pertikaian etnis. Dalam perang Balkan, khususnya perang Kroasia dan perang Bosnia, semua pihak dalam peperangan dipersalahkan melakukan pelangaran HAM, yaitu Kroasia, Muslim, dan Serbia. Meskipun demikian, terdapat perbedaan yang cukup antara pelanggaran yang dilakukan Kroasia dan Bosnia dengan pelanggaran dilakukan Serbia, baik mengenai gradasi keseriusan pelanggaran, maupun mengenai lingkup pelanggaran.

Hasil penelitian Helsinki Watch mengenai kejahatan perang di Bosnia Herzegovina menunjukkan bahwa sebagian besar pelanggaran yang dapat ditujukan kepada orangorang Kroasia dan kekuatan Muslim dilakukan oleh individu dan tidak muncul sebagai bagian dari suatu rencana yang disiapkan oleh pemerintah Bosnia dan komunitas Kroasia. Meskipun demikian, komunitas Kroasia Bosnia dan Muslim bersalah dalam hal pelanggaran serius hak asasi manusia dan hukum humaniter. Pelanggaran itu berupa perusakan barang-barang orang Serbia dan periakuan kejam terhadap sandera. ${ }^{41}$

${ }^{41}$ Helsinki Watch. 1993. War Crimes in Bosnia Hercegovina. Volume II. HIm. 7-8. 
Banyak pelanggaran ditujukan terhadap kekuatan Serbia yang telah lama diikuti, disadari dan dikenal sebagai pembasmian etnis (etnic cleansing), yang pertama kali digunakan dalam perang Kroasia dan juga dalam perang Bosnia. Tujuan utama kekuatan Serbia adalah untuk menangkap atau menguatkan kontrol terhadap daerahdaerah dengan cara pemindahan secara paksa dan pembunuhan orang non-Serbia. Di sebagian daerah Bosnia yang dikuasai Serbia, pelanggaran terhadap non-Serbia adalah hasil dari suatu rencana matang dari otoritas sipil lokal dan regional, otoritas militer dan-polisi. ${ }^{42}$

Penguasàan daerah Bosnia Herzegovina oleh Serbia dilakukan dengan penguasaan paksa yang memiliki kesamaan dengan "pola pembasmian etnis". Pola penguasaan itu dengan serangan artileri berat selama beberapa hari, minggu atau bulan. Akibatnya. banyak orang-orang sipil melarikan diri dari daerahnya selama penyerangan. Mengenai taktik yang dilakukan Serbia dikemukakan lebih lanjut: ${ }^{43}$

The attacks initially involve light and heavy artilery, which often is used indiscriminately and disproportionately in order to terrorize the local population and force it to flee from the besieged area. Even in cases where there is no armed resistance to Serbian attacks, the area is besieged solely for the purpose of displacing or terrorizing the population. In cases where armed resistance to Serbian troops is aimed at weak- ening the area's defenses and forcing the flight of its residents. After several hours, days or weeks of mortar attacks, thedefenses of the besieged village, town or city are weakened and Serbian infantry units enter the besieged are. Those who remain in the vicinity either are summarily executed or taken to detention facilities. Some are allowed to flee but often are shot at while retreating.

Kekejaman yang dilakukan Serbia terhadap perempuan dalam perang Bosnia diungkapkan R. Charli Carpenter dalam tulisannya Surfacing Children: Limitation of Genocidal Rape Discource. Dalam tulisannya dikemukakan: ${ }^{44}$

The ethnic conflict in the former Yugoslavia put war crimes against women on the international human rights agenda for the first time in history. In response to reports of tens of thousands of women being raped, mutilated, and executed in concetration camps as part of a systematic policy of ethnic cleasing, the international community took action against genocide for the first time since Nuremberg. In the process of addressing both rape and genocide, feminist legal scholars began to discuss rape as genocide, and their arguments hinged in large part on the evidence of a policy of forced impregnation. Evidence of forced impregnation helped excite moral sentiment because rape-induced

\section{${ }^{42} / \mathrm{bid}$.}

${ }^{43}$ lbid. HIm. 11.

${ }^{44}$ R. Charli Carpenter. "Surfacing Children: Limitations of Genocidal Rape Discourse."Human Rights Quarterly. Volume 22. Nomor 2. Mai 2000. 
pregnancy was persented as a worse crime against women than rape itself, and it helped frame rape as genocidal because of pregnancy's unique role in corrofing the victimized culture.

\section{Hasil dan Kesimpulan KPP HAM}

Kasus pelanggaran HAM berat terjadi pula dalam kasus Timor Timur sebagai dampak penentuan jajak pendapat rakyat Timor Timur pada tanggal 30 Agustus 1999 yang menghasilkan kemerdekaan bagi daerah tersebut. Kesimpulan itu merupakan hasil Komisi Penyelidik Pelanggaran (KPP) HAM Timor Timur yang telah melakukan investigasi di Timor Timur. Hasil penemuan komisi tersebut menjadi dasar Komnas HAM membuat suatu "Pernyataan Komnas HAM Tentang Kondisi HAM Di Timor Timur Pasca Jajak Pendapat.

Pelanggaran HAM yang terjadi di Timor Timur dilakukan secara terencana, sistematis serta dalam skala besar dan luas berupa pembunuhan massal. Pembunuhan massal yang menimbulkan banyak korban penduduk sipil dilakukan dengan sistematik dan kejam yang terjadi di berbagai tempat. Pembunuhan massal tersebut pada umumnya terjadi di tempat-tempat perlindungan seperti misalnya di gereja, kantor polisi dan markas militer. Adapun senjata yang digunakan adalah senjata dan senjata api oleh kelompok milisi bersama atau dengan dukungan aparat militer atau dibiarkan terjadinya oleh aparat militer dan kepolisian. ${ }^{45}$

Bentuk pelanggaran lainnya adalah penyiksaan dan penganiayaan. Penyiksaan dan penganiayaan dilakukan dalam skala besar, luas dan sistematik terhadap penduduk sipil yang pro kemerdekaan. Penyiksaan dan penganiayaan terjadi dalam berbagai momen yaitu sebelum pembunuhan dilakukan dan setelah penangkapan sewenang-wenang untuk tujuan-tujuan memeras informasi dari korban. ${ }^{46}$.

Pelanggaran HAM lainnya adalah penghilangan paksa yang dilakukan dengan pola (a) dalam rangka rekruitmen anggota milisi. Hilangnya sejumlah warga sipil merupakan akibat penolakan mereka untuk dijadikan anggota milisi, (b) penghilangan paksa juga terjadi sebagai usaha penundukan terhadap warga pendukung kemerdekaan, dan (c) penghilangan paksa terhadap sejumlah korban dari kalangan mahasiswa dan warga pendukung kemerdekaan juga dilaporkan terjadi sebagai kelanjutan dari aktivitas milisi di tempat-tempat pengungsian. ${ }^{47}$

Di samping itu, pelanggaran berat lainnya adalah perbudakan seksual dan perkosaan (kekerasan terhadap perempuan) yang terjadi di rumah, markas militer dan tempat-tempat pengungsian baik sebelum dan sesudah jejak pendapat., pembumihangusan, pemindahan dan pengungsian paksa, dan perusakan serta penghilangan barang bukti. ${ }^{48}$

${ }^{45}$ Pernyataaan Komisi Nasional Hak Asasi Manusia (komnas HAM) tentang Kondisi Hak Asasi Manusia Di Timor Timur Pasca Jajak Pendapat.

${ }^{46} /$ bid.

${ }^{47}$ Ibid.

${ }^{48}$ /bid. 
Dalam perang Kosovo juga terjadi pelanggaran HAM berat yaing dilakukan Serbia terhadap penduduk Kosovo keturunan Albania. Pelanggaran Ham tersebut merupakan tindakan yang dilakukan secara terencana, sistematis dan luas menyangkut pembasmian etnis, pengusiran paksa, penyiksaan dan pembunuhan secara kejam. Karena dinilai terlibat dalam melakukan kejahatan genosaid, kejahatan kemanusiaan dan kejahatan perang di Bosnia dan Kosovo, mantan presiden Serbia Slobodan Milosevic diadili di Mahkamah Internasional.

Adanya pelanggaran HAM berat tidak hanya terjadi dalam perang antar negara, tapi juga dalam konflik etnis di dalam negeri dan kekerasan yang dilakukan oleh rejim penguasa yang otoriter. Konflik etnis yang berkembang menjadi kejahatan genosaid terjadi di Rwanda pada awal 1990-an antara suku Huku dan suku Tutsi. Dalam skalä yàng lebih kecil terjadi dalam kasus Sampit di mana orang etnis Madura dibunuh oleh warga Dayak.

Kekejaman penguasa otoriter dapat disimak dari pembantaian yang dilakukan rejim komunis Khemer merah terhadap sekitar dua juta rakyat Kamboja, dan penghilangan dan pembunuhan lawan-lawan politik oleh Augusto Pinochet, yang berkuasa di Cile selama 17 tahun (1973-1983). Pinochet dituduh telah menghilangkan 1102 pembangkang. ${ }^{49}$

Dengan adanya peradilan pidana internasional, kejahatan genoșaid, kejahatan terhadap kemanusiaan, kejahatan perang, dan kejahatan agresi dapat dieliminasi melalui upaya peradilan terhadap para pelaku kejahatan tersebut. Prevensi umum terhadap kejahatan itu hanya akan timbul bila para pelakunya diadili dan dihukum. Namun upaya peradilan akan menemui berbagai kendala.

\section{Kendala Pelaksanaan Peradilan}

Peradilan pidana internasional akan menghadapi beberapa kendala dalam upaya mengadili para pelaku kejahatan genosaid, kejahatan terhadap kemanusiaan, kejahatan perang dan kejahatan agresi yang menjadi yurisdiksinya. Pertama, kedudukan peradilan pidana internasional sebagai institusi pelengkap bagi peradilan domestik yang dimiliki setiap negara anggotanya.

Dengan kedudukan seperti itu, peradilan pidana internasional. menjadi institusi peradilan sekunder yang baru bisa difungsikan bila peradilan domestik tidak melakukan peradilan terhadap para pelaku kejahatan genosaid, kejahatan terhadap kemanusiaan, kejahatan perang, dan kejahatan agresi. Apabila peradilan domestik mampu mengadili, maka kelemahan kedudukan peradilan pidana internasional itu terlihat dalam praktik peradilan terhadap tokoh-tokoh pelanggaran kejahatan kemanusiaan dan kejahatan perang di Kamboja dan Indonesia. Keinginan PBB untuk mengadili para pemimpin Khemer Merah yang dituduh melakukan genosaid (pembantaian) terhadap sekitar dua juta rakyat Kamboja pada masa pemerintahan Polpot ditolak oleh Perdana Menteri Kambodja, Hunsen. Hunsen meminta agar PBB mau menerima peradilan Kamboja bagi pelaku kejahatan genosasid yang terkenal dengan peristiwa the killing field, ladang pembantaian itu. ${ }^{50}$

${ }^{49} \mathrm{Harian}$ Kompas. Tanggal 16 September 2000.

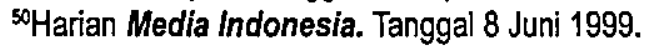


Dalam kasus pengadilan para tokoh Khemer merah melalui peradilan pidana Kamboja akan mengalami kesulitan àkibat sebagian tokoh Khemer Merah yang harus diadili duduk dalam kabinet pemerintahan yang sedang berkuasa. Para tokoh yang dimaksud misalnya leng Sary dan ke Paik.

Kasus yang sama dengan Khemer Merah terjadi pula dalam kasus pelanggaran HAM berat di Timor Timur yang dilakukan oleh milisi pro Indonesia dan TNI yang dituduh melakukan kejahatan kemanusiaan. Pada awalnya, 53 negara anggota Komisi HAM PBB bersepakat untuk membentuk peradilan HAM intemasional untuk mengadili pelaku kejahatan kemanusiaan di Timor Timur. Namun niat PBB itu menjadi surut karena Indonesia bermaksud mengadili sendiri para pelaku kejahatan kemanusiaan tersebut dengan hukum domestik Indonesia.

Karena Indonesia belum mempunyai ketentuan hukum mengenai peradilan HAM, maka DPR dan pemerintah membuat UU peradilan yang diatur dalam UU Nomor 28 Tahun 2001; Terhadap kasus pelanggaran HAM Timor timur itu kejaksaan agung telah menyelesaikan proses penyidikan dan telah menetapkan sejumlah tersangka, misalnya Abilio Soares (mantan gubernur Timor Timur), Eurico Guteres (komandan milisi Aitarak), FX. Tono Suratman (mantan Danrem 164 Wiradharma Dili), dan Timbul Silaen (mantan kepala Kepolisian Daerah Timor.Timur).

Kendala kedua berkenaan dengan masalah kesulitan mengumpulkan alat bukti (collecting eveidence). Kesulitan itu timbul karena peradilan pidana internasional, khususnya penuntut umum, tidak mempunyai kekuasaan pemaksa (coercive power) untuk memberikan arahan dan melakukan investigasi untuk mengumpulak bukti-bukti guna keperluan proses peradilan. Hal ini berbeda dengan peradilan domestik yang memberikan kekuașaan yang kuat kepada penuntut umum dalam melakukan pemeriksaan dan investigasi. ${ }^{51}$

Kesulitan mengumpulkan bukti-bukti itu tampak jelas dalam kasus Bleskic, komandan perang Kroasia (Croatian Defence Counci) di Bosnia Herzegovina. Penuntut umum Richard J. Ggoldstein menuntut Bleskic melakukan kejahatan kemanusiaan dan kejahatan perang. karena melakukan pengusiran warga Bosnia secara paksa dari kampung halamannya dan melakukan pembantaian. ${ }^{52}$

Dalam upaya mengumpulkan bukti-bukti kasus itu, atas permintaan kantor penuntut umum, Gabriel Kirk McDonald, hakim yang menjadi penuntut dalam kasus Bleskic mengeluarkan surat panggilan tertulis untuk menghadap sidang pengadilan (subpoenae duces tecum) kepada Republik Kroasia, Menteri Pertahanan Kroasia Gujko Susak, Federasi Bosnia Herzegovina, Pusat Penyimpanan Dokumen dan Daftar Tahanan Menteri Pertahanan Komunitas Kroasia di Herceg Bosnia. Kroasia segera menentang surat panggilan itu, dengan argumentasi bahwa peradilan pidana international tidak mempunyai otoritas untuk mengeluarkan perintah paksa terhadap negara dan pejabat tinggi negara tersebut, bahkan jika peradilan mempunyai

${ }^{51} \mathrm{Jacob}$ Katz Cogan. "The problem of Obtaining Evidence for International Criminal Court." Dalam Human Rights Quarterly. Volume 22. Nomor 2 Mai 2000.

${ }^{52}$ Ibid. 
kekuasaan itu, suatu negara masih mempunyai hak untuk membatasi. kepatuhannya untuk melindungi kepentingan keamanan negara: ${ }^{53}$.

Sejumlah dengan pendapat diadakan dengan arah untuk penegasan surat panggilan peradilan untuk menghadap: itu oleh suatu panel majelis hakim pada Juli 1997 dan kemudian dibatakkan oleh majelis peradilan hakim banding pada bulan Oktober tahun itu juga. Dengan demikian, peradilan-pidana internasional tidak mempunyai kekuasaan pemaksa untuk melakukan pemanggilan untuk menghadap sidang pengadilan terhadap negara dan pejabat-pejabat tinggi negara.

Cara baku yang biasa dilakukan dalam mengumpulkan bukti dalam peradilan pidana internasisonal adalah perjanjian saling membantu urusan hukum antara dua negara dan jalan diplomasi. Bila peradilan membutuhkan kerjsama seperti itu, penunutut umum atau penyidik mesti tergantung kepada negara untuk menyediakan bukti-bukti atau membuka jalan: untuk mendapatkan buktibuklti tersebut. Tanpa bantuan seperti itu maka peradilan tidak akan mendapatkan bukti-bukti yang memadai untuk pelaksanaan tugas mereka. ${ }^{54}$ '

Kendala ketiga adalah adanya disparitas kekuasaan ekonomi, politik, dan militer antara negara-negara anggota peradilan pidana internasional. Aspek kekuasaán ini menjadi kendala-karena efektivitas peradilan pidana internásional bukan hanya dipengaruhi oleh kerjasama pemerintah negara-negara yang

$53 /$ ibid.

54/bid.

s5Hariari Kompas. Tanggal 2 Juli 2001. melakukan 'kejahatan-dan tekanan rekonomi' dan politik -masyarakat internasional: $: \because ? \cdot$. $\because$ Dalamkasus penyerahan Milosevic,-mantan. Presiden Yugoslavia; kepada; Mahkamah Internasional, faktor yang menjadi penentunya bukan hanya tekanan politik masyarakat internasional, tapi juga keuntungan ekonomis yang didapat Yugoslavia berupa bantuan keuangan dari beberapa negara donor; seperti Amerika Serikat, Swiss, dan Perancis ${ }^{55}$ Dengan demikian, penyerahan Milosevic dibarter dengan bantuan ekonomi. , . . $r$

Karena efektivitas peradilan pidana internasional tergantung kepada kerjasama dengan pemerintah negara pelaku kejahatan dan tekanan politik, ekonomi, dan 'militer, maka para pelaku kejahatan genosaid, kejahatan kemanusiaan, kejahatan perang, dan kejahatan agresi yang. memiliki probabilitas tinggi dapat diadili melalui peradilan pidana internasional adalah penjahatpenjahat yang berasal dari dunia ketiga, bukan meraka.yang berasal dari negara-negara maju. Hal itu bisa terjadi karena negara-negara berkembang tidak memiliki kekuatan politik, ekonomi dan militer yang, memadai untuk mempengaruhi opini internasional mengenáa terjadinya pelanggaran kejahatan dalam yurisidksi peradilan. pidana internasional... .

- Negara-negara maju seperti-Amerika Serikat,-Rusia, Perancis; mempunyai kekuatan politik, ekonomi, dan militer. yang sangat kuat untuk, membentuk opini . publik dalam masyarakat internasional. AndaikataiAmerika

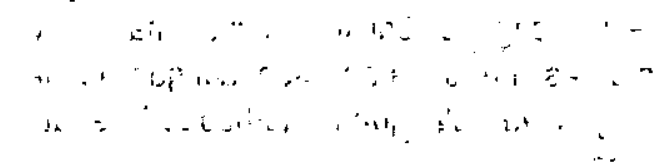


Serikat melakukan agresi terhadap suatu negara seperti yang pernah dilakukannya terhadap Grenada pada akhir 1980-an, apakah peradilan pidana internasional dapat mengadili pelaku yang berasal dari negara adidaya itu? Begitu pula halnya dengan Rusia yang pernah menginvasi Afganistan. Dengan demikian, kecil probabilitas mengajukan pelaku kejahatan genosaid, kejahatan kemanusiaan, kejahatan perang, dan kejahatan agresi yang berasal dari negara maju ke peradilan pidana internasional.

\section{Simpulan}

HAM adalah hak kodrati yang merupakan anugerah Allah kepada manusia untuk menjaga harkat dan martabat manusia sesuai dengan fitrak kemanusiaannya. Pengaturan HAM dalam sistem hukum nasional dan hukum internasional dimaksudkan untuk mempertegas komitmen suatu bangsa dan masyarakat internasioanal terhadap HAM tersebut. Perlindungan hukum pidana dan hukum pidana inernasional terhadap HAM dilakukan dengan cara melarang melakukan perbuatan-perbuatan yang melanggar HAM.

Peradilan pidana internasional merupakan instrumen PBB yang berfungsi melaksanakan tugas yudisial memeriksa, mengadili dan memutuskan hukuman bagi pelaku kejahatan genosaid, kejahatan terhadap kemanusiaan, kejahatan perang, dan kejahatan agreasi. Keempat kejahatan tersebut adalah kejahatan serius yang menjadi keprihatinan masyarakat internasional sekarang sehubungan dengan banyaknya pelanggaran terhadap kejahatan tersebut.

Peradilan pidana internasional mempunyai relevansi dengan perlindungan
HAM karena melindungi masyarakat dari praktik-praktik kejahatan genosaid, kejahatan terhadap kemanusiaan, kejahatan perang dan kejahatan agresi. Di samping itu, berbagai kasus pelangaran HAM berat yang terjadi di berbagai negara, Bosnia, Kroasia, Kosovo, dan Timor Timur, dan yang dilakukañ rejim otoriter, meyebabkan kehadiran peradilan pidana internasional semakin relevan.

Meskipun keberadaan peradilan pidana intèrnasional mempunyaì relevansi dengan perlindungan HAM, pelaksanaan peradilan pidana internasional menghadapi kendala kelemahan institusional, kesulitan pembuktian, dan diapraritas kekuasaan politik, ekonomi, dan militer di antara negara-negara anggota. Efektivitas peradilan pidana internasional akan diuji oleh sejarah.

\section{Daftar Pustaka}

Carpenter, R. Charli. "Surfacing Children: Limitations of Genocidal Rape Discourse."Human Rights Quarterly. Volume 22. Nomor 2. Mai 2000.

Cassese, Antonio. 1994. Hak Asasi Manusia Di Dunia Yang Berubah. Jakarta: Yayasan Obor Indonesia.

Cogan, Jacob Katz. "The problem of Obtaining Evidence for International Criminal Court." Dalam Human Rights Quarterly. Volume 22. Nomor 2 Mai 2000.

Davidson, Scot. 1994. Hak Asasi Manusia. Jakarta: Pustaka Utama Graviti.

Reksodiputro, Mardjono. 1994. Hak Asasi Manusia dan Sistem Peradilan Pidana. Jakarta: Pusat Pelayanan Keadilan dan Pengabdi Hukum ỤI. 
Shidiqi, Nourouzzạman dalam M: Lükman , Harian Kómipas. Tanggal 16 Septembér Hakim (ed). 1993. Deklarasi Islam Tentang HAM. Surabaya: Risalah Gusti. 2000.

Harian Media indonesia. Tanggal 8 Juni Watch, Helsinki. 1993. War Crimes in Bosnia 1999.

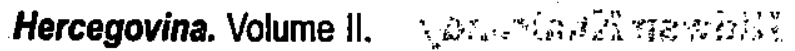

Harian Kompas.Tanggal 2 Juli 2001.

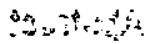

深深深

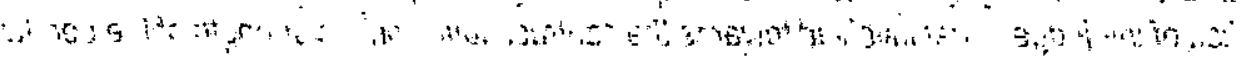

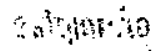

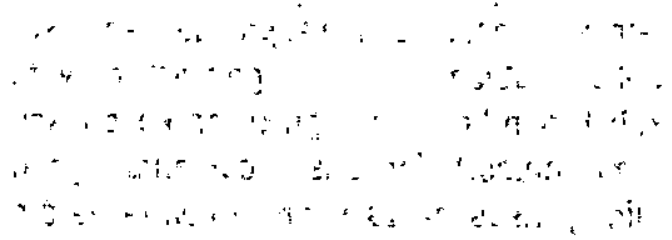

